\title{
A UTILIZAÇÃO DAS REDES SOCIAIS COMO DIVULGAÇÃO NO CONHECIMENTO DE CRUSTÁCEOS
}

\author{
Silva, A.S. ${ }^{1,}{ }^{*} ;$ Silva, L.T.F. ${ }^{1} \&$ Calado, T.C.S. ${ }^{1}$ \\ ${ }^{1}$ Universidade Federal de Alagoas (UFAL), Campus A. C. Simões, \\ Laboratórios Integrados de Ciências do Mar e Naturais. \\ *Autor correspondente: alberissantos001@gmail.com
}

\begin{abstract}
Crustáceos estão entre os grupos de invertebrados mais conhecidos da população, pois seus representantes fazem parte da alimentação de muitas famílias, confecções de artesanato e aquarismo. Apesar de ser um grupo tão familiar ainda existem dúvidas e mitos que podem ser explicados por profissionais da área da biologia. As mídias sociais podem contribuir neste quesito, visto que estas fazem parte do cotidiano de toda população e não é diferente na rotina dos discentes. Elas além de serem formas de comunicação, tornaram-se ferramentas que auxiliam no processo de propagar informações e ideias. Este trabalho tem como objetivo demonstrar que as redes sociais podem ser um instrumento disseminador de conhecimento científico contribuindo para o processo de ensino-aprendizagem. Foi utilizada a rede social Instagram do laboratório de carcinologia, que está em funcionamento desde o dia 05 de março/18. Para a realização das postagens o procedimento foi dividido em cinco etapas: $1^{\circ}$ passo, ocorre a seleção da espécie, $2^{\circ}$ passo os espécimes são fotografados, $3^{\circ}$ passo são coletadas informações dos espécimes em artigos, livros, monografias, dissertações e teses, $4^{\circ}$ passo as informações são avaliadas pela orientadora e corrigidas se necessário, $5^{\circ}$ passo ocorre a publicação no perfil do laboratório no Instagram, estas publicações são bem humoradas e possuem uma linguagem menos técnica para que possa atingir diversos públicos. O aplicativo oferece informações sobre as publicações e o público que acompanha o perfil. A maior parcela dos apreciadores é da região nordeste, a cidade Maceió (AL) apresenta maior percentual com 65\%, e Marechal Deodoro (AL) com 7\% e demais localidades somam 4\%. Com 63\% a faixa etária predominante é de jovens entre 18 a 24 anos, seguida por adultos de 25 a 34 anos, correspondendo a $30 \%$. Os seguidores em sua maioria são do gênero feminino equivalente a $59 \%$. Foi constatado que durante a semana em média 62 pessoas acessam a página e que 278 contas de 365 são alcançadas. Os horários com maior número de acesso são $12 \mathrm{~h}, 18 \mathrm{~h}$ e 21 h. Logo, pode ser observado que a ferramenta possui relevância, pois desperta o interesse sobre o grupo, ocasionando grande interação com os seguidores e entre os mesmos, através de discussões nas publicações e sugestões de postagens.
\end{abstract}

Palavras-Chave: tecnologia, informação sobre invertebrados, ensino de crustáceos. 